\title{
Juan Bautista Alberdi: EnTRe el MOdelo CAliforniano Y LAS TENSIONES DEL GOBIERNO "MIXTO"
}

\author{
[Juan Bautista Alberdi: Between the Californian Model and the Tensions of \\ the "Mixed" Government]
}

\author{
Eduardo Hodge Dupré* \\ Universidad de los Andes, Santiago, Chile
}

\begin{abstract}
RESUMEN
El siguiente trabajo intentará demostrar que la experiencia federal de Estados Unidos fue más influyente para el pensamiento constitucional del argentino Juan Bautista Alberdi de lo que sostienen algunos especialistas. Para defender esta postura, el artículo abordará dos temas fundamentales en los escritos del tucumano: el ejemplo organizacional de California durante la "fiebre del oro de 1848" y las nociones del "gobierno mixto", idea clave no sólo en la Constitución de Estados Unidos de 1787, sino también en la magna obra de Hamilton, Madison y Jay, El Federalista.

Palabras clave

Juan Bautista Alberdi - Federalismo Historia Constitucional - Argentina.
\end{abstract}

\begin{abstract}
This article attempts to demonstrate that the USA federal experience influenced Argentinian Juan Bautista Alberdi's constitutional thought more than some experts believed. In order to prove this, two essential subjects in the Tucuman writings are addressed: the Californian organizational initiatives during the "the 1848 Gold Rush" and the "mixed government" notion, which is a key idea not only in the Constitution of the United States of America of 1787, but also in the greatest work by Madison and Jay, The Federalist.
\end{abstract}

\section{KEYWORDS}

Juan Bautista Alberdi - Federalism Constitutional history - Argentina

ReCibido el 10 de noviembre de 2017 y ACEPTADO el 23 de mayo de 2018

* Doctor en Historia de América y Doctor (C) en Relaciones Internacionales. Profesor de la Facultad de Comunicación, del Instituto de Historia, del Centro de Estudios Generales y del Programa de Bachillerato de la Universidad de los Andes, Chile. Contacto: e.hodge.dupre@ gmail.com. Dirección postal: Mons. Álvaro del Portillo 12.455, Las Condes, Santiago. 


\section{INTRODUCCIÓN}

Ha sido frecuente que los estudiosos señalen que las propuestas federales de Juan Bautista Alberdi afloraron divorciadas del modelo de Estados Unidos ${ }^{1}$. Por una parte, están aquellos que argumentan que él más bien defendía la tesis de un gobierno m ix t o (es decir, "unitario y federalista”, en palabras de González Calderón ${ }^{2}$ ), con cierta inclinación hacia el unitarismo"; y por otra, los que han resaltado la influencia de otros modelos, como la Constitución chilena de $1833 .^{4}$ Ambas posturas están en lo correcto, pues Alberdi efectivamente pensaba que las Provincias del Río de la Plata debían ser organizadas por medio de un gobierno que equilibrara lo nacional con lo local -a eso se refería con $\mathrm{m}$ i x t $\mathrm{o}^{5}$-, tomando aspectos de su propia realidad, pero inspirándose en modelos constitucionales ex i to s o s. Alternativamente, lo que este trabajo intentará demostrar, es que

${ }^{1}$ Otros han utilizado argumentos más radicales. Por ejemplo, Zuccherino señaló que Alberdi habría desconfiado de todos los acercamientos llevados a cabo por Estados Unidos hacia América Latina y en particular hacia las provincias argentinas. En ello, no veía más que la prolongación de intereses nacionales. Al menos en las Bases, esta idea no está presente de ninguna manera. Para Mayer, por ejemplo, bastaba con que Alberdi señalara que los orígenes de ambas repúblicas fueran diferentes para concluir que sus sistemas federales también lo eran; véase ZuCCHERINO, R., Juan Bautista Alberdi, ideólogo del siglo XXI (Buenos Aires, 1987), p. xiv; MAYER, J., Alberdi y su tiempo (Buenos Aires, 1973), I, pp: 535, 595. Botana señaló que el tucumano "no tiene en cuenta a Estados Unidos sino como una de las fuentes de las que puede venir el peligro externo", y para ello utiliza como argumento los antecedentes que dio en Bases sobre el caso mexicano, país que había "perdido ya la mitad de su territorio". Pero tal como se indicará más adelante, lo que Alberdi hizo con ese caso fue demostrar el fracaso del régimen federal mexicano ante el progreso norteamericano; véase BotANA, N. Alberdi, Sarmiento y Mitre: tres proyectos de futuro para la era constitucional (Buenos Aires, 2004), p. 23. Tampoco es menor lo planteado por Díaz Arana, J.J., Influencia de Alberdi en la Constitución Nacional: juicio ante una controversia (Buenos Aires, 1947), p. 28: respecto a la influencia de la carta norteamericana, recomendaba que "era necesario no darle a dichas manifestaciones más alcance que el que tuvieron". Sin embargo, la postura más llamativa es la de Polotto, quien afirma con algo de radicalidad, que Alberdi representa a los intelectuales que han defendido el "sentido" y "aplicación nacional" del federalismo argentino, en oposición a los que reconocen su identidad con el norteamericano; véase Polotto, M. R., La argentinidad de la constitución. Nuevos enfoques para el estudio de nuestra carta magna a principios del siglo XX (1901-1930), en Revista de Historia del Derecho, 37 (Buenos Aires, 2009), p. 2.

2 GonZAlez Calderón, J. A., Introducción al derecho público provincial (Buenos Aires, 1913), p. 96; Barros, C. Alberdi, periodista en Chile (Buenos Aires, 1997), p. 344.

${ }^{3}$ Adelman, J., Between Order and Liberty: Juan Bautista Alberdi and the Intellectual Origins of Argentine Constitutionalism, en Latin American Research Review, 42/2 (Texas, 2007), p. 86. Otros como Halperin sostienen que Alberdi defendió siempre la tesis de un poder ejecutivo vigoroso; citado por Herrero, A., Juan Bautista Alberdi y su reflexión sobre América durante el régimen de Juan Manuel Rosas: (1835-1852), en Revista de Hispanismo Filosófico, 10 (Madrid, 2005), p. 9.

${ }^{4}$ Seco Villalba, J., Fuentes de la Constitución Argentina (Buenos Aires, 1943), p. 89 y ss. De todos modos es menester reconocer otras interpretaciones, como por ejemplo aquella que defiende la influencia francesa en el Río de la Plata durante la primera mitad del siglo XIX. Véase Herrero, A., cit. (n. 3), p. 2.

${ }^{5}$ Autores como Subercaseaux lo han llamado, cuestionablemente, "federalismo relativo". Véase SubercaseauX, B., Juan Bautista Alberdi: modernidad y modernizaciones en el siglo XIX, en Estudios Avanzados, 25 (Santiago, 2016), p. 9. 
Alberdi no sólo fue un federalista en estricto sentido, sino además pensó y diseñó sus Bases ${ }^{6}$ apoyándose en la experiencia norteamericana, a fin de replicarla en su propio contexto ${ }^{7}$. Se cree que este supuesto cobra fuerza en dos elementos presentes en su obra.

El primero es su análisis sobre la Constitución de California, que había sido sancionada en Monterrey el año 1849. Como se verá a continuación, el argentino veía en este nuevo Estado los mismos problemas que afectaban a las provincias argentinas (a saber, desorden social, desorganización política, debilidad institucional, etc. $)^{8}$. Se percató de que las soluciones que habían implementado los californianos eran similares a las que él esperaba ofrecer en su tratado. En efecto, analizando los sucesos acaecidos en el oeste norteamericano, vislumbró la factibilidad de organizar la república bajo el mismo sistema implementado por Estados Unidos en su carta fundamental, es decir, articulando un régimen que antepusiera lo nacional a lo local, sin que ambas esferas perdieran sus condiciones de soberanía y autonomía.

Y el segundo es el empleo mismo del concepto $\mathrm{m}$ i x t u r a . Cuando Alberdi lo utilizó en las Bases, no lo hizo para establecer diferencias respecto del ejemplo norteamericano, ya que su definición de federalismo era el mismo que contenía la carta de 1787 y los panfletos publicados por Hamilton, Madison y Jay en El Federalista (capítulo XL). No es posible determinar con certeza por qué subrayó tanto esta denominación, o si en realidad pretendió generar diferencias con el proyecto norteamericano. Lo que sí está claro, es que cuando habló de "federalismo mixto", lo hizo para referirse al sistema que equilibra muy bien las dos esferas nacional y local. Esto da motivos para que algunos sostengan que Alberdi había leído traducciones poco certeras del proyecto angloamericano9. De todos modos, sus conocimientos sobre teoría federal eran bastante sólidos. Sabía de lo que estaba hablando, a pesar de haber confundido a veces los términos federación y confederación, o bien algunas nociones del federalismo estadounidense.

En efecto, estudiar las ideas de Alberdi es un paso obligado para comprender el federalismo argentino. Y la razón fundamental radica en el encargo que le hizo el mismo Urquiza después de haber derrocado a Rosas en Caseros: elaborar los principios que sustentarían la carta fundamental que regiría las provincias argentinas a partir de ese momento. En el debate sobre si Alberdi fue o no relevante durante la Asamblea Constituyente de Santa Fe han participado importantes

${ }^{6}$ Alberdi, J. B., Bases y puntos de partida para la Organización Política Argentina (Buenos Aires, 2005).

${ }^{7}$ Esto, en parte, sintoniza con lo planteado con Levaggi, A., Manual de historia del derecho argentino: parte general (Buenos Aires, 1998), p. 330, quien reconoce que "la Constitución nacional -aludiendo a la Carta de 1953- cambió el sistema de manera decisiva, al apartarse de los modelos europeos y seguir al norteamericanos".

${ }^{8}$ Sobre la Constitución de California, Oliver propuso: "es verdad que esa Constitución no era la de una nación soberana, sino simplemente estatal o provincial, pero para Alberdi era éste un detalle sin mayor importancia”; vid. OLIVER, J. P., El verdadero Alberdi: génesis del liberalismo económico (Buenos Aires, 1977), p. 260.

9 Pérez Guilhou, D., El pensamiento conservador de Alberdi y la Constitución de 1853 (Mendoza, 2003). 
juristas e historiadores ${ }^{10}$. Más de alguno incluso llegó al extremo de comparar las Bases con la carta de $1853^{11}$. Pero más allá del grado de influencia, lo que sí importa es que el tucumano fue una voz autorizada para los diputados constituyentes, y muestra de ello son las constantes referencias y acercamientos que mantuvo con varios de ellos ${ }^{12}$. Es más, es posible sostener que su trabajo se mantuvo vivo durante el debate parlamentario. Uno de sus estudiosos actuales resumió su trascendencia de la siguiente manera: "Él se convirtió en uno de los liberales letrados más significativos de América Latina, en los tiempos que la ciudad de las letras gozaba de un significado histórico sin precedentes. Mejor conocidos como los textos fundamentales del constitucionalismo argentino, los cuales llevaron a cabo imaginar los fundamentos legales de la soberanía del estado tras la revolución y guerra civil, los escritos de Alberdi fueron también incursiones en análisis de la historia, y en algunos aspectos sirvieron con piedra de toque para cómo los argentinos comenzaban a ver su historia al tiempo que se esforzaban para hacerla"13.

\section{Alberdi EN EL TIEMPO: VIDA, OBRA E INSPIRACIONES}

Alberdi nació el 29 de agosto de 1810 en Tucumán, aunque residió desde muy joven en el puerto de Buenos Aires. Allí comenzó sus estudios de jurisprudencia, que posteriormente prosiguió en Córdoba y Chile. Entre otras actividades, participó en la fundación del Salón Literario (1835) y la Asociación de Mayo junto a Esteban Echeverría. Allí conoció a importantes pensadores de la talla de Marcos Sastre, Juan María Gutiérrez, José Mármol y Miguel Cané, quienes fueron perseguidos por conformar la incipiente Generación del 37. Entre los principales

${ }^{10}$ La diversidad de posiciones puede medirse en SAMPAY, A., La filosofia del iluminismo y la Constitución argentina de 1853 (Buenos Aires, 1944), p. 8; DANA, S., La Constitución de 1853 y sus autores e inspiradores (Santa Fe, 1943), p. 14; LINARES, S., Derecho Constitucional e instituciones políticas (Buenos Aires, 1981), p. 654; Galletr, A., Historia Constitucional argentina (La Plata, 1974), p. 503; FAYT, C., Fuentes de la Constitución Argentina (Buenos Aires, 1943), p. 76; García, M. et. al., Las fuentes de la Constitución Nacional. Los principios fundamentales del derecho público argentino (Buenos Aires, 2006), p. 43. Otros, sin embargo, han negado que la Carta fue una copia de dichas Bases; véase Levene, R., Historia de la Nación Argentina. Desde los origenes hasta la organización definitiva de 1862 (Buenos Aires, 1946), p. 242. Bosch, por su parte, cuestiona toda injerencia del Alberdi en la redacción de la carta fundamental, arguyendo la existencia de otros factores que habrían precedido a la tesis del autor; véase BosCH, B., $L a$ Confederación Argentina 1854-1868 (Buenos Aires, 1998), p. 11 y ss.

${ }^{11}$ Ferreyra, R., Orígenes. Sobre las 'Bases' de Juan Bautista Alberdi y la Constitución Federal en el tiempo, en Academia. Revista sobre enseñanza del Derecho, 19 (Buenos Aires, 2012), p. 143 y ss.

12 Zimmermann, E., Judicial Institutions in Nineteenth-century Latin America (Londres, 1999), pp. 109-110. Davis llegó a señalar lo siguiente: "The influence of Alberdi's book in Argentina may also be compared with that of the Federalist Papers in the United States. It is like this North-American counterpart not only in its influence on political thought, but also in being a book which belongs peculiarly to the age which produced it": véase DAVIS, H., Juan Bautista Alberdi, Americanist (Miami, 1962), p. 53. GonZÁlez Calderón, J. A., Doctrina constitucional: temas trascendentales de derecho politico. Derecho público provincial y municipal. Cuestiones de derecho y jurisprudencia constitucional (Buenos Aires, 1928), p. 83 concluyó que el trabajo de los diputados constituyentes "resulta notablemente superior al proyecto elaborado" por Alberdi.

13 Adelman, J., cit. (n. 3), p. 86. 
postulados de este movimiento, resaltaron la promoción de la democracia (o "socializarla" como lo denominaban ellos) ${ }^{14}$, el fin de la tiranía r o s i s ta, el establecimiento de la libertad, y la continuación de todas las reformas liberales propugnadas por la revolución de Mayo. Estas propuestas, sumado al hecho de no querer prestarle juramento al proyecto de Rosas, llevó a Alberdi y sus contertulios a disolver el Salón Literario y conformar una nueva logia con el nombre de $\mathrm{La}$ Joven Argentina. Producto de la persecución iniciada por la $M_{a z o r c a^{15}}$, en 1838 partió al exilio junto al resto del grupo.

Primero en la Banda Oriental y luego en Chile, Alberdi logró madurar todas las ideas relativas a la organización nacional de su país. En Montevideo ejerció labores de jurisprudencia, pero también logró impulsar importantes periódicos, como El Iniciador y El Corsario. A través de estos y otros medios, deslegitimó la tiranía de Rosas e impulsó la intervención francesa en el Río de la Plata. En 1843, luego de que fuerzas del general Oribe se levantaran en Montevideo, huyó a Europa junto a Gutiérrez, logrando establecerse en París. A fines de ese mismo año, viajó a Chile para radicarse en Valparaíso, donde estrechó lazos con Domingo Sarmiento quien, hasta ese momento, encabezaba a los disidentes argentinos residentes en la ciudad. Si en Europa pudo entrar en contacto con las obras de Montesquieu y Rousseau, en Chile profundizó la Constitución de Estados Unidos y El Federalista, de Hamilton, Madison y Jay ${ }^{16}$. Apenas terminada la Batalla de Caseros, y a petición del general Urquiza, Alberdi comenzó a redactar el "esbozo" ${ }^{17}$ que posteriormente inspiraría la Constitución argentina. Con el nombre de Bases y Puntos de partida para la organización política de la República Argentina, el tucumano esbozó los lineamientos esenciales del derecho público nacional, consagrando de esta forma el ideario de mayo $^{18}$.

Una vez consolidado el gobierno paranaense, el general Urquiza le ofreció algunos cargos públicos, pero los rechazó categóricamente. Lo que sí aceptó, fueron algunas misiones diplomáticas. En 1855 fue destinado a Europa para que obtuviera el reconocimiento internacional de la Confederación Argentina. Sus labores fueron interrumpidas en 1862, cuando el general Mitre venció a Urquiza

${ }_{14}$ Para referirse a Sarmiento, Lugones señaló lo siguiente a propósito de los fines de esta Generación: "constituir la democracia como hecho social, antes que como fórmula política, asegurando, así, el éxito trascendental de la independencia; vésase LugOnEs, L., Historia de Sarmiento (Buenos Aires, 1945), p. 125.

15 La Sociedad Popular Restauradora, más conocida como La Mazorca, fue creada a fines de 1833 por el gobernador de Buenos Aires Juan Manuel Rosas y sus partidarios, con el propósito de canalizar la acción política de los f e d e r a l e s. Se convirtió en un grupo de choque con efectos cada vez más intimidatorios contra los opositores. Los mazorqueros no vacilaron en recurrir a la violencia para conseguir sus objetivos intimidatorios y suprimir la oposición; véase Di Meglio, G., La Mazorca y el orden rosista, en Prohistoria, 12 (Rosario, 2009).

${ }^{16}$ Lizondo, M., Juan Bautista Alberdi: su vida y su obra (Tucumán, 1960), p. 8.

17 El término e s b o z o fue acuñado por Seco Villalba, J., Fuentes de la Constitución Argentina (Buenos Aires, 1943), p. 118.

18 Canal Feijoo, B., Alberdi. La proyección sistemática del espiritu de mayo (Buenos Aires, 1961). La relación entre Alberdi y Urquiza puede consultarse en CARCANO, R., Urquiza y Alberdi. Intimidades de una politica (Buenos Aires, 1938), pp. 3-7. 
en la batalla de Pavón, y la Confederación tuvo que iniciar un nuevo proceso de configuración. A su regreso fue elegido diputado por Tucumán, tribuna que le permitió presenciar los acontecimientos que llevaron a la federalización de Buenos Aires en 1880. Durante los últimos años de su vida, Alberdi fue hostigado por algunos representantes de la hasta entonces nueva generación política, entre quienes figuraba el general Mitre. Fue en este contexto en el que Alberdi desarrolló sus más importantes tesis sobre la paz internacional, publicadas en La Nación. Luego de varios entredichos y presiones políticas, decidió viajar a Francia para radicarse, donde murió el 19 de junio de 1884 .

La literatura no ha llegado a un consenso específico sobre las influencias que habría recibido Alberdi durante su vida intelectual. Dardo Pérez planteó incluso que el tucumano habría respondido a un habitual "eclecticismo sistemático", propio de su generación ${ }^{19}$. Eduardo Segovia puso énfasis en su cercanía con el utilitarismo inglés ${ }^{20}$, mientras que Coriolano Alberini destacó sus técnicas iluministas como las de $\mathrm{Mayo}^{21}$. Pero más allá de toda esta información, Alberdi desarrolló un pensamiento que era propio de sus circunstancias, y que Botana pudo precisar cuando sostuvo que había recurrido "a soluciones transaccionales, inspiradas en el pensamiento de la asociación”. Más adelante, el estudioso señaló: "sus Bases no son sino un esfuerzo ciclópeo por hallar las fórmulas jurídicas de esa conciliación, que arrancarán del análisis de la realidad”22. En ningún momento Botana vinculó esta idea con los planteamientos federalistas de Alberdi, pero los términos a s o cia ción y conciliación, que son fundamentales para la instauración de esta forma de gobierno, invitan a suponerlo.

En general, la historiografía escasamente ha tomado en cuenta las ideas federales de Juan Bautista Alberdi. Por el contrario, al igual que lo ocurrido con Sarmiento, los estudiosos han tendido a no profundizar en ellas, argumentando que sus enfoques se asociaban más al unitarismo que al federalismo ${ }^{23}$. Esta consideración es cierta, pero sólo en términos nominales. Alberdi y Sarmiento eran opositores de Rosas, que utilizaba la denominación federal sin serlo en la práctica, y no a la forma de gobierno ${ }^{24}$. En el Tomo III de sus Escritos Póstumos, Alberdi dio algunas luces de estas contradicciones: "No se pierda jamás de vista que cada vez que pronunciamos la palabra federación, aludimos a lo que Rosas llama federación, y la pronunciamos con risa, porque el mismo Rosas la pronuncia con risa. Por lo demás, nosotros nos guardamos bien de hablar con ligereza del hermoso sistema

19 Pérez Guilhou, D., cit. (n. 9), p. 17; véase Halperin, T., Prólogo, en Proyecto y Constitución de una Nación (Argentina 1846-1880) (Caracas, 1980), p. 26.

${ }^{20}$ Segovia, E., La historiografia argentina del romanticismo (Madrid, 1980), p. 195.

${ }^{21}$ Alberini, C., La metafísica de Alberdi (La Plata, 1966).

${ }^{22}$ Botana, N., El orden conservador, la política argentina entre 1880 y 1916 (Buenos Aires, 1977), p. 13.

${ }^{23}$ Un ejemplo emblemático de ello es la obra de Canal Fejjoo, B., cit. (n. 18), p. 146.

${ }^{24}$ Incluso los norteamericanos conocían esta singularidad del caso argentino. The daily dispatch (USA, 15 de mayo de 1852) evidenció: "The army of Urquiza was still unpaid, and it was supposed that a new issue of paper money by the Government Bank would be made for that purpose. Many reforms were taking place. Municipal governments like those of the United States, it was thought, would be organized: thus doing away with the centralization of Rosas". 
que han profesado Montesquieu, Rousseau, Washington, Hamilton, Madison, Tocqueville y Sismondi, sin más que porque un día se les antojó profanar la palabra federación a los bandidos López y Rosas. Cuando llegue la ocasión de dar nuestra opinión sobre el gobierno general, conveniente a la República Argentina nosotros iremos a tomar las tradiciones hermosas de Mayo un pensamiento que no diste nada casi del sistema federativo republicano" 25 .

Con ello, Alberdi aclaraba que el régimen porteño había deformado el término federación, y deja entrever que, hasta ese momento, no perdía las esperanzas de regir las provincias argentinas de acuerdo a esta forma de gobierno. Este documento dataría de 1838, por lo que es posible determinar que ya tenía para entonces algunas consideraciones de lo que significaba, en términos políticos, el sistema federal. Ello probaría que Alberdi se interesó por el federalismo norteamericano desde muy joven: "mi vida privada que se pasaba toda en la República Argentina, que fuera escrita en 1873. Mis lecturas favoritas por muchos años de mi primera edad fueron hechas en las obras más conocidas: El Federalista y [Joseph] Story"26.

El que podría ser considerado como uno de los primeros acercamientos de Alberdi a las doctrinas federalistas norteamericanas data de 1839, año en que permanecía exiliado en Montevideo. Después de que Lavalle fuera derrotado por las fuerzas rosistas, el tucumano redactó un artículo que tituló El fin de la revolución es la organización. En este texto propuso algunos postulados sobre el orden político y jurídico que luego deberían regular el interior de la Confederación Argentina. De esta forma dio las primeras señales de lo que posteriormente sería publicado en las Bases, encargadas por Urquiza. En sus Escritos Póstumos indicó: "Nosotros hemos creído muy oportuno y muy conducente comenzar desde luego a popularizar las doctrinas constitutivas que, en vista de las necesidades de nuestro país, nos han parecido las más adecuadas y más capaces de una adopción discreta y modificada. Son las más contemporáneas y dominantes también. Pertenecen, las más de ellas, por su origen a las prácticas de los Estados Unidos, y por su confección científica y sistema a los publicistas que privan en todas partes en estos momentos, tales como Sismondi, Tocqueville y Chevalier" 27 .

Con este comentario, Alberdi demostraba el interés que tenía por difundir entre sus compatriotas el modelo federal, el más idóneo -según su parecer- para organizar el escenario rioplatense. Pero existe otro dato que debe ser resaltado: el tucumano pensaba que el sistema político de Estados Unidos tenía el carácter de c i e n tíf i c o, es decir, se caracterizaba por estar comprobada su rigurosidad, exactitud y excelentes resultados. Esta posición la mantuvo vigente por varios años. En 1850 redactó un documento que tituló Carta sobre los estudios convenientes para formar un abogado, donde entregó algunos datos que no sólo evidencian su desinterés por seguir el modelo francés -tendencia bastante recurrente entre los pensadores liberales después de 1848-, sino también por la preponderancia del proyecto norteamericano en sus perspectivas políticas. En dicho documento expresó: "No gastaría yo tiempo en estudiar derecho político en Francia, por varias

\footnotetext{
25 Alberdi, J. B. Escritos Póstumos (Buenos Aires, 1902), III, p. 144.

${ }^{26}$ Ibíd., XV, p. 261.

${ }^{27}$ Ibíd., XIII, ps. 574-578.
} 
y buenas razones que me es fácil dar. Primeramente, porque la Francia misma no le tiene en el día y apenas sabe a qué derecho quedar, si el monárquico o republicano. Después de eso, en mi América, el derecho público es un instinto; tenemos más de un publicista distinguido que no le ha estudiado en las aulas. Nuestros hermanos del Norte han creado la organización más perfecta que conozca de la democracia sin tener escuelas ni autores célebres de derecho" 28 .

Para finales de la década de 1840, Alberdi había perdido el entusiasmo inicial por la realidad europea ${ }^{29}$. Lo que antes era arquetipo de civilización, ahora no era más que símbolo de monarquía, anarquía y desorden. Tal como lo señalara el mismo Pérez, la teoría política había comenzado una fuerte crisis con las revueltas de $1848^{30}$. No es posible determinar con exactitud, pero las mutaciones que estaba viviendo el sistema político europeo llevaron a Alberdi a interesarse más por la experiencia norteamericana que, hasta ese momento, gozaba de estabilidad, orden y progreso $^{31}$. Después de haber redactado la primera edición de las Bases, en un texto titulado De los medios de gobierno en las repúblicas de América del Sud, señaló que "el Federalista no es un tratado de demagogia; es la defensa del poder fuerte. Hamilton, Madison y Jay fueron gubernamentales, no despreciables demagogos" 32 . Así, Alberdi daba los primeros indicios sobre el enfoque republicano que deseaba instaurar en las provincias, fundado en un gobierno fuerte, pero que respetara la diversidad, tal como el sistema norteamericano.

La experiencia norteamericana estuvo presente desde los inicios de las Bases, obra que impulsaría, según su autor, el "mejoramiento indefinido de la especie humana", por medio de la colonización del desierto, la transmisión de las ideas y la "nivelación de las poblaciones con las subsistencias" que, según su parecer, estaban eclipsadas por el sistema colonial, causa principal de la "barbarie" americana $^{33}$. De este m e jor a m i e n t o también se desprende una segunda idea, y es que el orden, la paz y la institucionalidad contribuirían significativamente al bienestar social de la nación. El tucumano sustentó esta reflexión en el ejemplo norteamericano, al que vio cómo el modelo de civilización: "las trabas y prohibiciones del sistema colonial impidieron su población en escala grande y fecundada por los pueblos europeos, que acudían a la América del Norte, colonizada por un país de mejor sentido económico; siendo ésa una de las principales causas de su superioridad respecto de la nuestra" ${ }^{34}$.

${ }^{28}$ Alberdi, J. B., Obras Completas (Buenos Aires, 1960), III, p. 343.

${ }^{29}$ En la Introducción de sus Bases, Alberdi dejó claro que los modelos no debían hallarse en Europa.

${ }^{30}$ Pérez Gullhou, D., cit. (n. 9), p. 25.

${ }^{31}$ Alberdi, J. B., en Organización política y económica de la Confederación Argentina, señaló: "Tenemos la costumbre de no mirar otra cosa en aquel país que su Constitución general. A ella comúnmente atribuimos la suerte próspera de los Estados Unidos, y en gran parte es así; pero la raíz principal de su progreso y bienestar, la base más profunda y fuerte de sus libertades, reside en sus instituciones, en sus costumbres, en sus libertades municipales o comunales. Una gran parte del célebre Tocqueville se reduce a la demostración práctica de esta verdad”, p. 264.

32 Alberdi, J. B., Escritos, cit. (n. 25), IX, pp. 32-33.

${ }^{33}$ Alberdi, J. B., Bases, cit. (n. 6), p. 10.

${ }^{34}$ Ibíd. 
Cuando le correspondió analizar la situación constitucional de las provincias argentinas, Alberdi fue categórico al señalar que el triunfo sobre Rosas marcaba el inicio de una nueva etapa, que lograría la organización e impulsaría el progreso. Su relevancia fue tal, que la comparó con la revolución de Mayo, no sólo porque la batalla de Caseros había llegado a destruir los últimos vestigios de la época colonial, sino también porque las provincias se encontraban, al igual que en 1810, en la "necesidad de crear un gobierno general" y "una Constitución que sirva de regla de conducta a ese gobierno". Su diagnóstico era pesimista y a la vez realista: "la República Argentina carece hoy de gobierno, de Constitución y de leyes generales", por lo cual resultaba fundamental para el triunfo de la organización nacional, "crear un gobierno nacional y una Constitución general que le sirva de regla" 35 .

Alberdi reconoció que los modelos no debían hallarse en el resto de las naciones latinoamericanas. El único caso que merecía atención era Chile, aunque también valoró el uruguayo ${ }^{36}$. Aseguró que "todo el derecho constitucional de la América antes española es incompleto y vicioso", y que "ninguna de las constituciones de Sudamérica merece ser tomada por modelo de imitación" ${ }^{37}$. Y una de las principales razones que dio Alberdi para sostener esto, era que todos los proyectos constitucionales que se habían sancionado en la región, eran reformas de Cartas ya existentes, unas pensadas "para robustecer el poder en provecho del orden; otras de debilitarlo en beneficio de la libertad". El problema radicaba, entonces, en que todo se había reducido a la independencia y la democracia, olvidando aspectos vitales como la riqueza, el progreso, el comercio, la industria ${ }^{38}$, entre otros ${ }^{39}$. Al parecer, Alberdi sintió el llamado para superar esto: "todo ha cambiado en esta época: la repetición del sistema que convino en tiempos y países sin analogía con los nuestros, sólo servía para llevarnos al embrutecimiento y a la pobreza" ${ }^{40}$.

35 Ibíd.

${ }^{36}$ Alberdi dedicó todo el apartado IV para resaltar las virtudes del proyecto chileno; de acuerdo con Alejandro Herrero, cit. (n. 3), p. 7, la admiración de Alberdi por el modelo uruguayo se habría gestado en sus días de exilio durante el régimen de Rosas.

${ }^{37}$ Alberdi, J. B., Bases, cit. (n. 6), p. 16.

${ }^{38}$ En este ámbito hay una estrecha relación con los liberales mexicanos, que desde 1855 en adelante publicaron una serie de artículos que buscaban reivindicar el valor de la industria. Uno de los tantos ejemplos es La industria es la riqueza del mundo, difundido en El Monitor Republicano (México, 16 de abril de 1856): "Tal es el sentir de un sabio que cree ver en los destellos de la luz que derrama por el universo, una semejanza de la columna de fuego que guiaba a los israelitas en el destierro; la industria que, cual astro benéfico recorre en el siglo presente todos los pueblos, precediendo en su marcha los goces positivos alcanzados por el trabajo. La felicidad que acarrean a los pueblos la industria fabril, esa varilla mágica que como encanto transforma los productos más simples y abandonados del hombre en asombros prodigiosos obrados por el poderoso agente de una máquina”.

39 Alberdi, J. B., Bases, cit. (n. 6), p. 17. En Escritos Póstumos (I, p. 101), Alberdi hizo la conexión entre democracia y progreso económico, observado el ejemplo norteamericano. Al respecto señaló: "La democracia de América debe la condición económica que le hace ser lo que es, no a estudios sabios, no a doctrinas a priori, sino al cultivo especial de la ciencia económica que nacía en 1776, con la república americana, justamente Smith daba a luz su libro en este mismo año. Ella es la obra espontánea de las cosas y de las circunstancias en que se encontraban los pobladores y fundadores de esas sociedades de Norteamérica”.

${ }^{40}$ Alberdi, J. B., Bases, cit. (n. 6), p. 20. 


\section{CALIFORNiA EN EL PENSAMIENTO ALBERDiano}

Al comenzar la segunda mitad del siglo, nuevas ideas habían arribado a las provincias argentinas ${ }^{41}$. Los proyectos de 1819 y 1826 quedaron en el pasado, por lo que era necesario pensar y establecer ciertos enfoques que sintonizaran con las nuevas preguntas que rápidamente iban apareciendo, relativas al progreso material y la organización nacional ${ }^{42}$. El tucumano tenía la claridad suficiente ante esto: "he aquí el fin de las Constituciones de hoy día: ellas deben propender a organizar y constituir los grandes medios prácticos de sacar a la América emancipada del estado oscuro y subalterno en que se encuentra" ${ }^{43}$. En esta misma línea, planteó que las Constituciones deben ser "contratos mercantiles de sociedades colectivas, formadas especialmente para dar pobladores a estos desiertos, que bautizamos con los nombres pomposos de Repúblicas; para formar caminos de hierro, que supriman las distancias que hacen imposibles esa unidad indivisible en la acción política" ${ }^{44}$.

Después de pasar revista a la historia constitucional argentina, y de exaltar las ideas de progreso, Alberdi dio las primeras luces de la experiencia californiana, dedicando todo el apartado IX de las Bases para recoger de ella lo más importante, y así fundamentar sus planteamientos federales: "tengo la fortuna de poder citar en apoyo del sistema que propongo el ejemplo de la última Constitución célebre dada en América, que es la confirmación de nuestras bases constitucionales”. Su promulgación había sido el 12 de octubre de 1849 en Monterrey, luego que un grupo de delegados decidiera entregarle al poblado un marco jurídico que regulara el desorden y el bandidaje producido por las enormes olas de inmigrantes que arribaban buscando nuevas oportunidades ofrecidas por la fi e b r e d el or o . Para Alberdi, esta Constitución era "la aplicación simple y fácil al gobierno del nuevo Estado de derecho constitucional dominante en los Estados Unidos de la Unión de Norteamérica”. Para el autor, "ese derecho forma el sentido común, la razón de todos, entre los habitantes de aquellos venturosos Estados" ${ }^{4}$.

California le había mostrado a Alberdi no sólo la factibilidad de ordenar la realidad interna de las provincias argentinas bajo la modalidad federal, sino

41 Lorenzo, C., Manual de Historia Constitucional Argentina (Rosario, 1997), II, cap. 2.

${ }^{42} \mathrm{Al}$ parecer, entre los argentinos existía una estrecha relación entre el comercio y el sistema de gobierno que iban a implementar para iniciar el proceso de organización nacional. El Nacional (Buenos aires, 4 de junio de 1853) publicó una nota que comprueba esta idea: "Apenas ha desflorado la margen de ese continente con la población y la labranza; su vasto interior está intacto. El corazón del país es un punto comercial y no será tocado sino por el poder del vapor y por el uso libre de esas corrientes majestuosas. Es de suma importancia establecer en esa región colonias, mandar allí emigrantes, vapores, el hacha y el arado como mensajeros del comercio que vamos a emprender. Veamos pues, primeramente en qué estado está ella, y cuán lejos de aquel en que debería estar, y cual su condición actual, y así nos hallaremos habilitados para juzgar mejor el verdadero sistema de política que deberían adoptar a su respecto todas las provincias comerciales".

43 Alberdi, J. B., Bases, cit. (n. 6), p. 40.

${ }^{44}$ Alberdi, J. B., Bases, cit. (n. 6), p. 41.

45 Ibíd., pp. 41-42. 
también la posibilidad de iniciar un proceso de ordenación política y social sin tener grandes referencias legales, intelectuales y políticas inmediatas. Tampoco dejó de llamar su atención el poco tiempo que demoraron en sancionar la Carta fundamental que produjo efectos inmediatos ${ }^{46}$. En sus palabras: "Sin universidad, sin academias ni colegios de abogados, el pueblo improvisado de California se ha dado una Constitución llena de previsión, de buen sentido y de oportunidad en cada una de sus disposiciones. Se diría que no hay nada de más ni de menos en ella. Al menos no hay retórica, no hay frases, no hay tono de importancia en su forma y estilo: todo es simple, práctico y positivo, sin dejar de ser digno" ${ }^{47}$.

Pero de acuerdo con Alberdi, las soluciones aplicadas al problema californiano respondieron a un proceso más amplio. Pocos años antes, dicho territorio estaba fuera de todo circuito c i v i l i z a t o r i o. En él reinaba "la soledad y desamparo bajo el sistema republicano de la América española”. Todo habría cambiado gracias a los aportes entregados por la "civilización vecina", que motivada por la "incivilidad e injusticia” del régimen s a n t a n is t a "tomó posesión del rico suelo y estableció en él sus leyes de verdadera libertad y franquicia”. Luego prosiguió: "en cuatro años se ha erigido en Estado de la primera República del universo el país que en tres siglos no salió de oscurísima y miserable aldea" ${ }^{\text {". }}$. Para el argentino, los problemas que atañían a California solo se habían resuelto con su anexión a la jurisdicción estadounidense. Este hecho le permitió conocer y disfrutar del paradigma liberal, el libre comercio y la protección del gobierno federal, elementos que para él habían sido determinantes en el mejoramiento aurífero de la región.

"El oro de sus placeres ha podido concurrir a obrar ese resultado. Pero es indudable que bajo el gobierno mexicano ese oro no hubiera producido más que tumultos y escándalos entre las multitudes de todas partes, agolpadas frenéticamente en un suelo sembrado de oro, pero sin gobierno de tolerancia y de progreso, harán más que el oro la grandeza del nuevo Estado del Pacífico. El oro podrá acumular miles de aventureros, pero sólo la ley de la libertad hará de esas multitudes y de ese oro un Estado civilizado y floreciente. La ley fundamental de California, tradición de la libertad de Norteamérica, está calculada para crear un gran pueblo en pocos años" ${ }^{49}$. Esta referencia hace patente que la ecuación de Alberdi era simple: California estaba destinada a ser una gran potencia no por su oro, sino por la instauración de instituciones liberales que estaban siendo transmitidas por Estados Unidos ${ }^{50}$. Este ejemplo puede ser considerado como

46 Sarmiento tuvo la misma apreciación: "Sueño, empero, que han realizado todos los pueblos civilizado, que se repite por horas en los Estados Unidos, y que California ha hecho vulgar en un año, sin gobierno, sin otro auxilio que la voluntad individual contra la naturaleza en despecho de las distancias. [...] Doce años ha bastado para producir en California estos asombrosos resultados”; Sarmiento, D.F. Argirópolis (Buenos Aires, 1913), p. 95. En otro momento, habría mencionado el autor: "mientras que California se ha hecho Estado de la Confederación en dos años, la República Argentina, que ya tiene 40, todavía es pupila, según el general Rosas”. Véase Barros, C., cit. (n. 2), p. 436.

47 Alberdi, J. B., Bases, cit. (n. 6), p. 42.

48 Ibíd.

49 Alberdi, J. B., Bases, cit. (n. 6), p. 42.

${ }^{50}$ En El Nacional (Buenos Aires, 11 de agosto de 1852) se puede encontrar un editorial 
un motivo suficiente para interesarse por el federalismo. Alberdi sabía que las provincias argentinas no tenían oro en las cantidades de California, pero sí recursos naturales y canales de comunicación ${ }^{51}$ que no estaban siendo explotados de manera efectiva por el solo hecho de carecer de instituciones e impulsos liberales que, entre otras medidas, facilitarían la masiva inmigración de europeos a las provincias del interior (de ahí su lema "gobernar es poblar" ${ }^{52}$ ), eliminarían las aduanas interiores y redimirían al comercio fluvial de los monopolios que desde la colonia imperaban en Buenos Aires ${ }^{53}$.

Lo que más entusiasmó a Alberdi de la Constitución californiana fue su esencia liberal y federal. De hecho, la mayoría de los artículos analizados por él hacían referencia a estos temas. Por ejemplo, sobre la cuestión liberal señaló que "el pueblo de California" "goza de todos los derechos, privilegios y prerrogativas del ciudadano mismo, en lo tocante a la libertad civil, a seguridad personal, a inviolabilidad de la propiedad, de la correspondencia y del tránsito" ${ }^{54}$. Y sobre lo federal, Alberdi destacó dos materias. La primera hacía referencia a sus artículos 3 y 4, de los cuales se desprende el valor de la representatividad por Estado contemplado en esta forma de gobierno. Hablando específicamente de la cuestión inmigratoria, y de los aportes de los extranjeros en el ámbito legislativo, parafraseó a jurista norteamericano Joseph Story con el propósito de contar con

que muestra esta misma idea: "La inmigración ha levantado a los Estados Unidos; y si hemos encontrado adecuada a nuestro sistema su Constitución, hemos tomado cuanto encierra de benéfica, hagamos también como la unión que ha sabido desenvolver un sistema poderoso de asimilación, que ha producido riquezas, nombre y ciudadanos".

${ }^{51}$ Como se verá en el capítulo dos de esta investigación, los norteamericanos estaban conscientes de que las provincias argentinas eran ricas en recursos naturales. La prensa de la época señalaba: "For thousands of miles these immense rivers are navigable, safely and easily, by sailing vessels and by those propelled by steam. They water vast countries, rich in the products of tropical climate, although the despotism which has hitherto governed them has paralyzed the development of their resources both in population, means of transportation, and agriculture and manufacture. The precious metals, iron, copper, lead, salt, alum, gypsum, sulphur, mineral pitch, coal, cotton, tabaco, rice, sugar, indigo, wheat, maze, wines, pepper, cochineal, aloes, cocoa, dyes, fruits, abound -in short the list of vegetable and mineral productions opens throughout thirty degrees of latitude, and from the Atlantic to the Andes, a field for European and American enterprise the importance and extent of which cannot be realized at a cursory glance such as we are forced to give. A glance at the map, at the wide and fertile regions through which these rivers flow and which, are now for the first time, rendered accessable to commerce, will best assist the reader in forming a conception of the magnitude of the advantages placed by Urquiza's liberal policy before the world of traffic". The Primitive Republican (25 de noviembre de 1852).

52 Véase Zambonini, A., El mensaje de Alberdi, gobernar es poblar (Buenos Aires, 1950).

53 En una de las cartas enviadas a Sarmiento en 1853, Alberdi se refirió a la importancia de seguir los pasos de los norteamericanos en materias de libertad fluvial. En dicho documento, y luego de debatir sobre las salidas de los ríos, el tucumano aludió a las leyes sancionadas en 1792 por la colonias angloamericanas a propósito de la navegación del Mississippi: "no habría razón, pues, para que la América del Sud no consagre esta misma doctrina en sus leyes de navegación mediterránea. Ella debe dar absoluto acceso al tráfico naval de sus ríos, en favor de toda bandera americana y con cortas limitaciones de cualesquiera otra bandera, sin exclusión"; véase ALBERDI, J. B.. Obras, cit. (n. 28), IV, p. 89.

${ }^{54}$ Alberdi, J. B., Bases, cit. (n. 6), p. 43. 
legisladores que fueran capaces de velar primero por lo nacional y luego por lo local: "Se ha notado con razón que mediante las condiciones de capacidad fijadas por la Constitución, el acceso al gobierno federal queda abierto a los hombres de mérito de toda la nación, sean indígenas, sean naturalizados, jóvenes o viejos, sin miramientos a la pobreza o riqueza, sea cual fuere la profesión de la fe religiosa" ${ }^{55}$.

La segunda está relacionada con temáticas de tipo comercial, como los impuestos y los créditos. De los primeros destacó la igualdad sobre todas las propiedades del Estado y las contribuciones directas que, según su punto de vista, eran las únicas que convenían a "países llamados a recibir del exterior todo su desarrollo, en lugar del impuesto aduanero" ${ }^{56}$. Y sobre los créditos, el tucumano puso en relieve la prohibición que tenía la legislatura para otorgar privilegios a las entidades bancarias, cumpliendo así con uno de los requerimientos más habituales de la doctrina federal: "prohíbe terminantemente la emisión de todo papel asimilable a dinero por bancos de emisión, y sólo tolera los bancos de depósito”, establecido en las secciones 31 y 35 del artículo $4^{\circ}$ de la carta local.

Alberdi utilizó el ejemplo de California para demostrar que el sistema federal mexicano estipulado en la Constitución de 1824 había sido la principal causa de la pérdida territorial, debido a su incapacidad para resolver los problemas de la tolerancia religiosa y la reticencia para instaurar un régimen liberal. Luego de asegurar que el país "debía estimularse con el grande espectáculo de la nación vecina", no dudó en insistir que "ese sistema ha conducido a México a perder Texas y California, y lo llevará quizás a desaparecer como nación”. Alberdi estaba convencido de que "el poblador extranjero no es un peligro para el sostén de la nacionalidad", sino más bien el motor del progreso y la modernización ${ }^{57}$. Después de analizar la Constitución uruguaya, señaló: "la constitución americana que desampara el porvenir, lo desampara todo, porque para estas repúblicas de un día, el porvenir es todo, el presente poca cosa" ${ }^{58}$.

Alberdi pensaba que la experiencia californiana marcaba el término de una etapa y el comienzo de otra. A los principios de libertad y democracia, se añadían otros como el progreso, la industria y la cultura, que venían a consolidar los proyectos que, en algún momento, habían quedado inconclusos durante los años de la emancipación. Era una muestra concreta de que el régimen hispano colonial había fracasado ante el nuevo constitucionalismo liberal de tipo federal, corriente que tenía en su esencia el progreso y la modernización (al menos así lo concebía Alberdi y otros intelectuales latinoamericanos, entre ellos Sarmiento, de acuerdo con la experiencia norteamericana). Pero también recurrió a este ejemplo para argumentar la viabilidad de organizar las provincias argentinas en base a este régimen, en tanto que sus condiciones eran bastante parecidas: tanto en California como en Argentina había desorden e inestabilidad porque había ausencia de instituciones fuertes que regularan a la población, cada vez más masiva y heterogénea. En sus palabras, citó el ejemplo californiano para "hacer ver que no son

\footnotetext{
55 Ibíd.

56 Ibíd., p. 44.

${ }^{57}$ Ibíd., pp. 33-34.

58 Ibíd., 36.
} 
novedades inapelables las que yo propongo, sino bases sencillas y racionales de la organización de todo país naciente, que sabe proveer, ante todo, a los medios de desenvolver su población, su industria y su civilización, por adquisiciones rápidas de masas de hombres venidos de fuera, y por instituciones propias para atraerlas y fijarlas ventajosamente en un territorio solitario y lóbrego" 59 .

La velocidad con la que California se había ordenado institucionalmente fue uno de los motivos que impulsó a Alberdi para tomarla como modelo. Esto denota la prisa que tuvo para organizar las provincias del Plata con el mismo método empleado por los norteamericanos. Aseguró que la "improvisación de cuatro años ha realizado la fábula y hecho conocer la verdadera ley de formación de los nuevos Estados de América, trayendo de fuera grandes piezas de pueblos, acomodándolas en cuerpo de nación y dándoles la enseña americana”, y que ese $\mathrm{m}$ il agro no se produjo por la fi ebre del or o sino por la "libertad, que antes de improvisar a California improvisó los Estados Unidos", que representaba para el tucumano la "grandeza y la prosperidad". Luego acotó: "y si es verdad que el oro ha contribuido a la realización de ese portento, mejor para la verdad del sistema que ofrecemos, que la riqueza es el hada que improvisa los pueblos"60.

Cuando Alberdi redactó las Bases, California era el principal polo de atracción de América. Miles de personas llegaban por el Pacífico o por las rutas interiores buscando oportunidades laborales, tanto en el ámbito minero como en otros servicios (como construcción de líneas férreas o sistemas de comunicación). Esto habría llamado profundamente la atención del argentino, que veía cómo los inmigrantes europeos preferían Estados Unidos sobre las provincias argentinas. ${ }^{61}$ Esta podría ser una de las razones que llevó al tucumano a poner tanto interés en que la organización nacional fuera expedita, de modo que estas masas también se interesaran por el Plata. En sus palabras, "las poblaciones, que arrojadas de Europa por la guerra civil y las crisis industriales, atraviesan por delante de las ricas

59 Ibíd., p. 44.

${ }^{60}$ Ibíd., p. 92.

${ }^{61}$ El general Tomás Iriarte publicó en El Nacional (Buenos Aires, lunes 16 de mayo de $\left.1852, \mathrm{~N}^{\circ} 14\right)$ una nota que permite pensar que los argentinos deseaban el orden para facilitar la inmigración, tomando como ejemplo la experiencia angloamericana: "Es cierto que los Estados Unidos surgieron como pueblos independientes en una época de perturbación universal en toda la Europa, a consecuencia de la revolución francesa que estalló en 1789; que las guerras y su cortejo obligado de calamidades, empujaba la población fuera de sus playas natales para buscar paz y bienestar en aquellas regiones nuevas y casi por explotar en su mayor extensión; y que esta circunstancia especial favoreció inmensamente la afluencia de la emigración a los Estados Unidos. Es cierto también, que no podía ser de otro modo, porque en la época a que nos referimos eran aquellos estados los únicos en la América de ambos hemisferios en donde era posible la inmigración europea por el resto de esos dos continentes estaba todavía sujeta al régimen colonial. ¿Pero y después? ¿Desde que nos hemos emancipado, en qué puede consistir que esas grandes masas de inmigración europea se transporten todavía en estos momentos a los Estados de la Unión Americana, prefiriéndolos a los nacientes y despoblados estado de lengua castellana, dotados, como hemos dicho, por la naturaleza de las condiciones más esenciales de rápido incremento y de inagotables manantiales de prosperidad?”. 
regiones del Plata para buscar en California la fortuna que podrían encontrar allí con más facilidad, menos riesgos y sin alejarse tanto de Europa"62.

\section{EL GOBIERNO MIXTO, A LA USANZA NORTEAMERICANA}

Después de analizar la experiencia californiana, Alberdi explicó la orientación política del gobierno que tenía en mente. Partía de la base de que toda nación debía ordenarse de acuerdo con sus circunstancias. Es más, llegó al punto de pensar que "el hombre no elige discrecionalmente su Constitución gruesa o delgada, nerviosa o sanguínea", como tampoco hay voluntad respecto a redactar una Carta monárquica o republicana, federal o de tipo unitario. "Él recibe-prosiguió- estas disposiciones al nacer: las recibe del suelo que le toca por morada, del número y de la condición de los pobladores con que empieza, de las instituciones anteriores y de los hechos que constituyen su historia". Sin embargo, inspirándose en las teorías de Montesquieu, que él mismo había referenciado, precisó que "las Constituciones deben ser adecuadas al país que las recibe"63.

Si bien Alberdi destacaba las bondades del unitarismo, terminó inclinándose por el federalismo. Al menos eso reflejan sus análisis sobre la historia del Río de la Plata: "pero veamos ahora los antecedentes normales y poderosos que hacen imposible por ahora la u $\mathrm{n}$ i d a d i n d i v i s i b l e del gobierno interior argentino, y que obligaría a todo sistema de gobierno central a dividir y conciliar su acción con las soberanías provinciales, limitadas a su vez con el gobierno general", sobre todo en los temas administrativos de la república. Esta acotación evidencia que Alberdi manejaba una definición cabal del federalismo, poniendo en duda que solo conocía traducciones mal hechas. Defendía esta forma de gobierno porque era idónea para su país, constituido por provincias que no sólo eran diversas e independientes entre sí, sino que además varias de ellas estaban aisladas, debido a las enormes y costosas distancias que las separaban, y a la falta de una infraestructura que las comunicara. Ello habría engendrado distintas costumbres legales, sistemas monetarios y soberanías parciales ${ }^{64}$.

Alberdi advirtió que la discusión constituyente debía considerar por igual los elementos unitarios y los federales, argumentando que ambos formaban parte de la historia e idiosincrasia argentina. Era necesario tomarlos en cuenta, porque ellos eran la base de la "Constitución escrita, que ha de ser expresión de la Constitución real, natural y posible”. Fue en este contexto en que Alberdi comenzó a referirse al "sistema mixto", pensándolo como una relación entre los elementos unitarios y federales. De manera muy resumida, lo definió como la conciliación

${ }^{62}$ Alberdi, J. B., Bases, cit. (n. 6), p. 91.

${ }^{63}$ Ibíd., pp. 77-78.

${ }^{64}$ Ibíd., pp. 81-82. Entre los antecedentes unitarios destacó: unidad de origen hispánico en la población; unidad de creencias y culto religioso; unidad de costumbres e idioma; unidad política y de gobierno, pues todas las provincias formaban parte de un solo Estado; unidad de legislación civil, comercial y penal; unidad judiciaria; unidad territorial, bajo la denominación de virreinato de la Plata; unidad financiera o de rentas y gastos públicos; la ciudad de Buenos Aires constituida en capital del virreinato. 
de "las libertades de cada provincia y las prerrogativas de toda la Nación”, pensada como la "solución inevitable y única, que resulta de la aplicación a los dos grandes términos del problema argentino, -la nación y la provincia”. Según su posición, la conexión entre ambas variables facilitaría la transición de la política antigua a la moderna, que consistía "en la combinación armónica de la individualidad con la generalidad, del localismo con la nación, o bien de la libertad con la asociación” ${ }^{65}$.

El autor de la Bases estaba convencido de que no estaban las condiciones para que las provincias argentinas se organizaran bajo las lógicas puras del unitarismo o del federalismo. A propósito de los primeros, aseguró que un gobierno general p e r m a n e $n$ t e era el medio más efectivo para cautelar el buen funcionamiento de la Constitución. No dio espacios para dudas, porque "de las tres formas esenciales de gobierno que reconoce la ciencia, el monarquismo, el aristocrático y el republicano, este último ha sido proclamado por la revolución americana como el gobierno de estos países". A esto fue necesario añadir el carácter democrático, “esencia misma del gobierno". Si bien planteó que las modalidades federal y unitaria eran meros accidentes, "un accesorio subalterno", lo cierto es que "las cosas han hecho prevalecer el federalismo, como regla del gobierno general"

En sus distintos trabajos, Alberdi demostró conocer bien lo que era el federalismo. Sin embargo, cuando aseguró que "la voz federación significa liga, unión, vínculo", produce algunas dudas. Estas se agudizan aún más cuando se pregunta “¿cuál será el grado conveniente a la República Argentina?”. Con ello dejaba entrever que existían varios modelos, pues ponía en un mismo nivel el federalismo y la confederación. Algunos estudiosos toman esta pregunta para poner en duda los conocimientos de Alberdi sobre esta forma de gobierno ${ }^{67}$. Pero todo se restablece cuando aclaró que el federalismo era algo más que "una simple alianza de provincias independientes", y que la existencia de una Constitución transformaba todo el escenario. Más adelante aclaró que, de acuerdo a los antecedentes y a los sucesos que en ese momento estaban ocurriendo, "la República Argentina será y no podrá menos de ser un Estado Federativo, una república nacional, compuesta de varias provincias, a la vez independientes y subordinadas al gobierno general creado por ellas"68.

Alberdi pensó que el gobierno federal central o gen e ral eran prácticamente lo mismo: "una federación concebida de este modo tendrá la ventaja de reunir los dos principios rivales en el fondo de una fusión, que tiene su raíz en las condiciones naturales e históricas del país" ${ }^{69}$, y que era finalmente el propósito que se había establecido previamente en el acuerdo de San Nicolás de los Arroyos. También creyó que las nociones unitaristas debían ser abandonadas por convencimiento, pues las condiciones de las provincias requerían otros mecanismos organizativos que tuvieran en cuenta la diversidad. En este

${ }^{65}$ Ibíd., pp. 82-83.

${ }^{66}$ Ibíd., p. 94.

67 BAQUÉ, S., Influencia de Alberdi en la organización política del Estado Argentino (Buenos Aires, 1915), p. 85.

${ }^{68}$ Alberdi, J. B., Bases, cit. (n.6), p. 94.

69 Ibíd., p. 95. 
sentido, argumentó que el espacio de "doscientas mil leguas cuadradas en que se deslíe", además de la escasa población disgregada por el territorio, impedían políticas únicamente centralistas. De hecho, aseguró que "la distancia es origen de soberanía local"70. Desde su punto de vista, esta situación habría gatillado la crisis de la Constitución de 1826, redactada por unitarios que no conocían las provincias, ni la cotidianeidad de cada una de ellas: "Como lo general de los legisladores de la América del Sur, imitando las constituciones de la revolución francesa, sancionaron la unidad indivisible en países vastísimo y desiertos, que, si bien son susceptibles de un gobierno, no lo son de un gobierno indivisible" 71 .

A pesar de sus contrariedades o eventuales fragilidades, el federalismo era la opción de Alberdi. Sabía que la pobreza material de las provincias, la escasa cultura de su gente y la baja densidad demográfica podían afectar la organización nacional, formando un gobierno i n c o m p le t o. El tema, es que de todos modos veía al federalismo como un proceso i n e $\mathrm{v}$ i t a b $\mathrm{l} \mathrm{e}^{72}$. Esto lo planteaba al mismo tiempo en que aclaraba que el unitarismo no era viable porque hacía desaparecer, absorbía e impedía el normal funcionamiento de los gobiernos locales, fusionándolos hasta formar un gobierno nacional. En definitiva, temía lo mismo que Hamilton y sus colegas al momento de redactar los artículos difundidos en El Federalista: que ascendiera un gobierno que sometiera a las provincias, tal como lo había hecho Buenos Aires durante la primera mitad del siglo $\mathrm{XIX}^{73}$. En sus planteamientos también estaban presentes los hechos de Francia y del Virreinato de la Plata, que se habían organizado políticamente "por la obra de conquistadores y del poder realista y central del que dependían”. Luego continuó: “¿Sería éste el medio de formar nuestra unidad? No, porque sería injusto, ineficaz y superfluo, desde que hay otro medio posible de organización. Si el poder local no se abdica hasta desaparecer, se delega, al menos. Este será el mejor medio posible de componer un gobierno general sin que desaparezcan los gobiernos locales. [...] Los unitarios no han presentado un mal principio, sino un principio impracticable en el país, en la época y en la medida que ellos desean"74.

Uno de los aportes más sustanciales de Alberdi fue concluir que la nación debía ser organizada bajo un gobierno que equilibrara lo nacional con lo federal. Pensaba que el centralismo gubernamental y el federalismo radical eran igualmente invia-

70 Ibíd.

71 Ibíd.

72 Ibíd., p. 97.

73 Cabe destacar, que tanto Alberdi como Sarmiento, Mora y Gómez Farías tuvieron enormes desconfianzas hacia los regímenes centralistas. En el caso del tucumano, esta percepción se vio con mayor fuerza en AlBerd, J. B., Organización política y económica de la Confederación Argentina: "Toda centralización es obra de la fuerza. La fuerza obra de dos modos: por las armas, por los intereses. [...] Lo que hacen hoy las provincias argentinas confederadas para convertir en hecho práctico las libertades de navegación fluvial y de comercio, que se iban quedando escritas delante de la costumbre robustecida por dos siglos de monopolio, es precisamente lo que hizo el pueblo de los Estados Unidos para tomar parte en la grande Unión esencial a la libertad común, a dos Estados que resistían incorporarse por mantener sus ventajas relativas de mercados más antiguos y puertos más frecuentados”, p. 230.

${ }^{74}$ Alberdi, J. B. Bases, cit. (n. 6), p. 97. 
bles para administrar las provincias argentinas. Sostuvo que un gobierno general y común a todas las provincias confederadas no era sano para el sistema, porque no garantizaba el factor más preponderante de todos, que era la heterogeneidad del territorio. En segundo lugar, "una alianza, una liga eventual de poderes iguales e independientes absolutamente" 75 era susceptible de ser revocada por alguna de las partes firmantes, debilitando la unión. Alberdi tuvo la misma convicción de los federalistas norteamericanos al sostener que sólo una alianza perpetua e indisoluble iba a asegurar su proyección en el tiempo ${ }^{76}$. Es más, descartó "toda idea de nacionalidad o fusión, pues toda alianza deja intacta la soberanía de los aliados"77. A fin de cuentas, estas eran particularidades que Alberdi quería evitar en el proceso de organización de las provincias argentinas.

Con cierta cuota de radicalidad, el tucumano sostuvo: "se han engañado cuando han creído que no había más federación que las simples y puras alianzas de poderes independientes e inconexos". Esta observación puede ser considerada como el principal fundamento para demostrar que el "gobierno mixto" (en el fondo, una federación con gobierno vigoroso) no era otro que el pensado por los norteamericanos y plasmado en la Constitución de Filadelfia, es decir, un sistema que "no es una simple federación, sino una federación compuesta, una federación unitaria y centralista, digámoslo así y por eso precisamente subsiste hasta la fecha y ha podido hacer la dicha de aquel país". Alberdi había comprendido que la etapa confederal de las colonias angloamericanas había sido un verdadero fracaso, y que la instalación del proyecto federal había sido la raíz de su estabilidad y progreso ${ }^{78}$.

Cuando analizó en perspectiva histórica la discusión entre unitarios y federales, Alberdi detectó algunos elementos asociados a la influencia norteamericana. Sostuvo que el unitarismo rivadaviano había sido una copia defectuosa del modelo francés, y que el federalismo de Dorrego no era sino una réplica entusiasta pero imperfecta de la experiencia norteamericana, que intentó conocer durante el poco tiempo que estuvo en dicho país. Refiriéndose al otrora partido federal, Alberdi aseguró que "ellos confundían la Confederación de los Estados Unidos del 9 de julio de 1778 con la Constitución de los Estados Unidos de América, promulgada por Washington el 17 de septiembre de 1787”. Con esto dejaba en claro que la Confederación había arruinado el proyecto republicano, mientras que la federación había sido la causa de la o p u l e n c i a que gozaban. Más adelante aseguró que la Constitución de 1787 había promovido "un sistema mixto federal y unitario". ${ }^{79}$

Después de discutir sobre las ventajas y desventajas del unitarismo y del federalismo, Alberdi determinó que era el momento de iniciar un nuevo proceso. Por ello aclaró que "las cosas felizmente nos traen hoy al verdadero término, al término medio, que presenta la paz entre la provincia y la nación, entre la parte y el todo, entre el localismo y la idea de una República Argentina". "Será pues, nuestra forma normal de un gobierno mixto, consolidable en la unidad de un

\footnotetext{
75 Ibíd.

76 Ibíd.

77 Ibíd., p. 104.

78 Ibíd.

79 Ibíd, p. 105.
} 
régimen nacional", pero no indivisible como en el pasado (como la Carta de 1826 al menos), sino uno fragmentado en provincias cuyos gobiernos estuvieran recíprocamente limitados con el gobierno central, por una Constitución legitimada por cada una de ellas. Con esto, Alberdi demostraba conocer la condición fundamental del federalismo, el mismo de los norteamericanos, y que ahora buscaba emular en su patria: "si la imitación no es por sí una sola razón, tampoco hay razón para huir de ella cuando concurre motivo de seguirla" 80 .

$\mathrm{Al}$ momento de analizar los componentes del gobierno $\mathrm{m}$ i x t o , Alberdi reconoció con cierto énfasis, que el "mecanismo del gobierno general de Norteamérica nos ofrece una idea de modo de hacer práctica la asociación de los principios en la organización de las autoridades generales" ${ }^{\prime 1}$. Admitió con claridad que Estados Unidos era un modelo factible y pertinente porque sus condiciones históricas habían sido similares a las argentinas, especialmente por la tensión que protagonizaron federales y unitarios. Sin embargo, Alberdi no asumió en ningún instante que tenía la intención de trasplantar la experiencia norteamericana al contexto rioplatense. Al menos así lo da a entender cuando planteó que "la asimilación discreta de un sistema adaptable en circunstancia análoga no es la copia servil, que jamás puede ser discreta en política constitucional"82.

Los elementos constitutivos de este gobierno $\mathrm{m}$ i x t o son básicamente los mismos que los estipulados en la Constitución norteamericana. A propósito del poder Legislativo, se pensó: debía estar dividido en dos cámaras, una destinada a representar por igual a las unidades provinciales, y otra que interpretara las necesidades del pueblo, como "si todas las Provincias formasen un solo Estado argentino"; en este punto, la proporcionalidad por habitante se vuelve un factor necesario. "Así tendremos un Congreso general formado de dos Cámaras que será el eco de las provincias y el eco de la nación. Congreso federativo y nacional a la vez, cuyas leyes serán la obra combinada de cada Provincia en particular y

${ }^{80}$ Ibíd.

${ }^{81}$ Ibíd., p. 108.

${ }^{82}$ Ibíd. En uno de los primeros estudios sobre el pensamiento de Alberdi, García Mérou citó una fuente en la que el tucumano habría señalado que el acuerdo entre los argentinos era una condición fundamental para lograr el orden y la estabilidad nacional en un momento de tanta algidez política. En ese sentido, llamó a replicar lo mismo que habían hecho los norteamericanos. A saber: "Jefferson, Franklin, Madison y el mismo Washington desaprobaron y se opusieron vivamente a puntos muy graves de la constitución mientras se discutía, pero desde el instante de su sanción por la mayoría del Congreso y del país, sellaron su labio y sólo tuvieron por ella el respeto religioso que todo buen republicano debe a la voluntad nacional. Es imposible tener leyes de otro modo. No puede haber dogma ni ley ante el examen que no sabe detenerse y respetar algún límite. El que discute su deber está en camino a desconocerlo. Hay un punto de honor en no discutir las leyes juradas de la República”. Según García Mérou, esta frase estaba dirigida a Sarmiento después de haber publicado Comentarios; véase GARCía Mérou, M. Juan Bautista Alberdi (Ensayo crítico) (Buenos Aires, 1890), p. 238. Sin embargo, todo indica que el sanjuanino subrayó esta misma idea en Argirópolis (la importancia de hacer respetar la ley ante todo): "Los Estados Unidos de Norte América, tan celosos de sus libertades de estados confederados, sancionaron al organizar la federación, que si las tres cuartas partes de los Estados reconocían la Constitución, estos compelerían por la fuera de las armas a los disidentes a conformarse con ella” (p. 43). 
de todas en general". Las condiciones propuestas por Alberdi para los otros dos poderes también estuvieron en sintonía con el norteamericano ${ }^{83}$.

Otra de las primicias del sistema federal que quiso poner en relieve fue la relación del gobierno central con las unidades provinciales. Sobre esto, señaló: "La creación de un gobierno general supone la renuncia o abandono de cierta porción de facultades por parte de los gobiernos provinciales. [...] Según esto, pedir un gobierno general, es consentir en el abandono de la parte del gobierno provincial que ha de servir para la formación del gobierno general; y rehusar esa Proción de poder, bajo cualquier pretexto, es oponerse a que exista una nación sea unitaria o federativa. La federación, lo mismo que la unidad, supone el abandono de una cantidad de poder local, que se delega al poder federal o central" ${ }^{\prime 4}$.

Teniendo en cuenta el verdadero sentido del sistema federal, Alberdi tuvo la convicción de que el gobierno central debía ejercer la autoridad sobre las unidades al igual que en el caso norteamericano, pero sin transformarse en una tiranía. ${ }^{85}$ Ante todo, el gobierno debía hacer cumplir la Constitución y cautelar el orden interno de la nación. Por ello era necesario que tuviera poder en el interior mismo de las provincias, porque de lo contrario sería "un gobierno sin objeto". No impulsar esto era dejar inerme el objetivo fundamental de la federalización, que en pocas palabras era "generalizar y unir ciertos intereses [...] para dirigirlos por un gobierno común y general. [...] Nada se consigue sin la unión de las fuerzas y facultades dispersas [...] En política no hay existencia nacional, no hay Estado [...] si no hay consolidación o unión de ciertos intereses"86. Aplicado esto mismo

${ }^{83}$ Alberdi, J. B., Bases, cit. (n. 6), pp. 108-109.

${ }^{84}$ Ibíd., p. 113.

${ }^{85}$ Un número importante de estudiosos ha señalado que en la $\mathrm{m}$ i x t u r a radica la diferencia que quiso establecer Alberdi con Estados Unidos, olvidando que una de las consignas más recurrentes de El Federalista de Hamilton, Madison y Jay fue precisamente que el nuevo proyecto político que estaban elaborando debía contemplar un gobierno fuerte. De hecho, años después se publicó en sus Obras póstumas: "no es la construcción, es la dirección de la nave de su gobierno lo que importa aprender a imitar a los Estados Unidos", insistiendo de alguna manera que la experiencia del norte se destacó precisamente por la sobrevaloración del poder central dentro del régimen federal. Entre quienes ven en la $\mathrm{m}$ i x t u r a la gran diferencia entre los postulados de Alberdi y la experiencia norteamericana, véase MASNATTA, H. et al., Constitución nacional: análisis de su reformar (Buenos Aires, 1993), p. 18; GARGARELLA, R., La sala de máquinas de la Constitución. Dos siglos de Constitucionalismo en América Latina (18102010) (Buenos Aires, 2014), p. 74, señaló que el tucumano, cuando propuso la instalación de un "gobierno fuerte", enfatizó la Constitución chilena, pues de la norteamericana, solo extrajo el valor de los "frenos y contrapesos".

${ }^{86}$ Alberdi, J. B., Bases, cit. (n. 6), p. 114. En otro de sus clásicos, Alberdi destinó un capítulo entero donde analizó la preponderancia del gobierno federal, poniendo como ejemplo la experiencia norteamericana. En el apartado Guerra y marina, el tucumano aseguró que el gobierno nacional estaba investido de todas las facultades necesarias para proveer la seguridad y defensa de la confederación, ya sea de amenazas internas o externas. Incluso con un tono donde predomina su inclinación por la paz, señaló que declarar y hacer la guerra no era sino "el medio extremado y doloroso de obtener" la paz. Sólo la república tenía la facultad de declarar la guerra y estados de sitio, pues sus efectos son siempre nacionales. Por ello era necesario contar con fuerzas militares nacionales, como el país modelo: "En la federación de Estados Unidos, haría reír la idea de una escuadra de Nueva Orleans, de un ejército de Pensilvania; de un general de 
al caso argentino, sostuvo: "La unión argentina constituye nuestro pasado de doscientos años y forma la base de nuestra existencia venidera. Sin la unión de los intereses argentinos, habrá provincias argentinas, no República Argentina; ni pueblo argentino: habrá riojanos, cuyanos, porteños, etc., no argentinos. Una provincia en sí es la impotencia misma, y nada hará jamás que no sea provincial, es decir, pequeño, oscuro, miserable, provincial, en fin, aunque la provincia se apellide Estado. Sólo es grande lo que es nacional o federal. La gloria que no es nacional, es doméstica, no pertenece a la historia. El cañón extranjero no saluda jamás la bandera que no es nacional" 87 .

Pero el fortalecimiento de la nación también requería de progresos materiales, por eso sostuvo que los "caminos de fierro, canales, puentes, grandes mejoras materiales, empresas de colonización son cosas superiores a la capacidad de cualquier provincia aislada, por rica que sea”. El tucumano sabía que un gobierno federal era el único capaz de fortalecer la nación y solventar los gastos de modernización. Muchas de las provincias vivían en condiciones mínimas y con recursos sumamente escasos ${ }^{88}$. Por ello era necesario levantar un gobierno federal sólido institucionalmente, que proyectara una imagen internacional coherente e incentivara políticas comerciales aperturistas, cuyos tributos irían en directo beneficio de las arcas fiscales que financian los gastos en infraestructura ${ }^{89}$. "Así, la existencia exterior del país será inevitablemente uno de los objetos que se constituyan nacionales. En este punto, la consolidación deberá ser absoluta e indivisible: para el extranjero [...] ésta debe ser una e indivisible: multíplice por dentro unitaria por fuera" engrandecimiento; es el alma de la paz y del orden, como es el agente del rey de la guerra. Sin él la República no tendrá caminos, ni puentes, ni obras nacionales, ni ejército, ni marina, ni gobierno general, ni diplomacia, ni orden, ni seguridad, ni consideración exterior" ${ }^{91}$.

Alberdi sabía que la instauración del federalismo no iba a ser una tarea fácil. Al menos así lo dejó en claro cuando aseguró que este "gobierno general y local a la vez, será complicado y difícil, pero no por ello dejará de ser el único gobierno posible para la República Argentina" ${ }^{2}$. Sin embargo, insistir en ello era una condición sine qua non para alcanzar los objetivos que él y otros liberales como Sarmiento se habían fijado: superar las fases del desorden, progresar y modernizarse, tal como lo había logrado Estados Unidos ${ }^{93}$. Más adelante aclaró: "esta fórmula

Nueva York. Allí solamente los Estados Unidos, es decir, la Nación, tiene esas cosas, en virtud del principio sentado de que a la república unida corresponde el poder de crear y organizar ejército, como le incumbe a ella sola el poder de hacer la guerra y la paz"; Alberdi, J. B., Organización, cit. (n. 73), p. 233.

${ }^{87}$ Alberdi, J. B., Bases, cit. (n. 6), p. 114.

${ }^{88}$ Ibíd., pp. 114-115.

${ }^{89}$ De acuerdo a Baqué, el tucumano consideraba la civilización como un "estado material", íntimamente relacionado con las ideas de progreso; véase BAQUÉ, S. cit. (n. 67), p. 85.

${ }^{9}$ Alberdi, J. B., Bases, cit. (n. 6), p. 116.

91 Ibíd., p. 120.

92 Ibíd., p. 122.

${ }_{93}$ No deja de ser interesante el dato ofrecido por Luis Suárez: "La Constitución de 1853 
-aludiendo al federalismo- no es original. Es la que resolvió la crisis de ocho años de vergüenza, de pobreza y de desquicio, por la cual pasó la Confederación de los Estados Unidos antes de darse la forma mixta que hoy tiene”. De todos modos, para Alberdi esto no era "plagio ni copia servil de una forma exótica", que dejaba de serlo desde que era "aplicable a la organización del gobierno argentino" 44

Esto último puede estar o no sujeto a crítica, pues la frontera entre i n s p i r a c i ó n e i m i t a c i ó n es casi imperceptible, al menos en este caso. Alberdi sabía que los fundamentos del federalismo norteamericano eran distintos al argentino. Que las provincias del Plata tenían un origen común, basado en el sistema colonial-centralista, mientras que las colonias angloamericanas eran unidades autónomas antes de los acuerdos confederales. El tucumano señaló al respecto: "este antecedente, por ejemplo, hará que la adopción argentina del gobierno compuesto de la América del Norte, entre más porción de centralismo, más cantidad de elemento nacional, que en el sistema de Norteamérica". ${ }^{95}$ Esto estaba en estrecha vinculación con las limitaciones que había pensado para los gobiernos locales, que son básicamente los mismos que aparecen en el Constitución de 1853. Luego de indicar algunos como la incapacidad de poseer ejércitos locales y aduanas propias, sostuvo enfáticamente: "nada de eso pueden hacer los Estados aislados en la Confederación de Norteamérica, a pesar de su soberanía local"96.

Es evidente que Alberdi había propuesto un gobierno fuerte para la Confederación Argentina, y en este sentido la Constitución chilena era su modelo. Pero cuando sostuvo que éste sería "uno de los rasgos en que nuestra Constitución hispano argentina debe separarse del ejemplo de la Constitución federal de los Estados Unidos", daba la impresión de que efectivamente había leído una mala traducción de la Carta norteamericana, o bien, hecho una interpretación errónea sobre ésta, puesto que en ninguno de sus artículos indicó que el gobierno central perdía poder ante los Estados. Por el contrario, él mismo debía garantizar que la Carta fundamental se aplicara en todo el territorio. La idea de Alberdi fue básicamente la misma de los norteamericanos: “¿Teméis que el ejecutivo sea su principal infractor? ¿Lo haréis omnímodo y absoluto, para hacerlo responsable? No; en vez de dar el despotismo a un hombre, es mejor darlo a la ley. Dad al poder ejecutivo todo el poder, pero dádselo por medio de una Constitución" 97 . En efecto, Alberdi sabía que era el momento preciso para superar la anarquía por medio de un gobierno macizo y vigoroso: "la paz sólo viene por el camino de la ley”, indicó más adelante ${ }^{98}$.

Cuando profundizó en la relación entre el gobierno central y los Estados

había supuesto el triunfo del federalismo, 'el término de la anarquía, el principio de orden y de la ley', como aseguró el presidente Urquiza, quedando en ella reflejados los principios ideológicos de la época, es decir, el liberalismo moderado y romántico [...]"; véase SuÁreZ, L., Historia general de España y América (Madrid, 1989), XV, p. 363.

${ }^{94}$ Alberdi, J. B., Bases, cit. (n. 6), p. 122.

${ }^{95}$ Ibíd., p. 123.

${ }^{96}$ Ibíd., p. 125.

${ }^{97}$ Ibíd., p. 128.

${ }^{98}$ Ibíd., p. 129. 
particulares, Alberdi cayó en una contradicción. Señaló que la renuncia de las provincias para revisar, ratificar o cuestionar la Constitución era un paso decisivo para el normal funcionamiento del régimen federal. Indicó que "el deseo de conservar íntegro el poder local hallará siempre pretextos para desaprobar una constitución que disminuye la autoridad de los gobiernos de provincia”, debido al arraigo alcanzado por los intereses locales y a la ausencia de un gobierno central que respondiera ante las demandas nacionales. Alberdi declaró que esta situación "es exigida por una necesidad de nuestra situación especial”, y que debían "adoptarlo, aunque no esté conforme con el ejemplo de lo que se hizo en Estados Unidos, donde los espíritus y las cosas estaban dispuestos de muy distinto modo que entre nosotros" ${ }^{99}$ Es cierto que las realidades de Argentina y Estados Unidos eran diferentes, pero cuestionar que los norteamericanos no consideraron esos mismos puntos, podría reflejar un posible error interpretativo del autor ${ }^{100}$.

\section{REFLEXIONES FINALES}

Alberdi tenía la esperanza de que todo el caos producido por las pugnas políticas sería resuelto con la Constitución federal; que con ella, a la que llamó la "carta de navegación" de la república, se iniciaba una nueva etapa de la historia argentina; y que por fin las condiciones estaban a favor del orden, del progreso y de la organización nacional, tan esperada desde los tiempos de la independencia. De todos modos sabía que las condiciones no eran las mejores, especialmente por la diversidad de intereses provinciales y la separación unilateral de Buenos Aires. Luego de cuestionarse si iba a ser factible terminar con los poderes locales (o caudillos), propuso que la Constitución debía imponer la verdad, la lealtad y la probidad a lo que él denominó "los intereses opuestos". En esta misma línea señaló: "El pacto político que no se ha hecho con completa buena fe, la constitución que se reduce a un contrato más o menos hábil y astuto, en que unos intereses son defraudados por otros, es incapaz de subsistir, porque el fraude envuelve siempre un principio de decrepitud y muerte. La Constitución de los Estados Unidos vive hasta hoy y vivirá largos años, porque es la expresión de la honradez y de la buena fe" ${ }^{101}$.

En efecto, si bien no lo reconoció directamente, todo indica que Alberdi diseñó las Bases con el propósito de replicar el modelo federal estadounidense en las provincias argentinas ${ }^{102}$. Los estudiosos citados en un comienzo han reiterado

99 Ibíd., p. 157.

${ }^{100}$ Para más información sobre la noción de "gobierno fuerte" entre los federalistas norteamericanos, véase WoOD, G. The idea of America. Reflections on the Birth of the United States (Nueva York, 2011).

101 Alberdi, J. B., Bases, cit. (n. 6), p. 161.

102 En trabajos posteriores planteó ideas que incluso podrían desmentir este supuesto, como por ejemplo en AlBerdi, J. B., Estudios sobre la Constitución Argentina de 1853: Examen de la Constitución Provincial de Buenos Aires sancionada en 1854 (Buenos Aires, 1929), donde aseguró que "para disolver la unidad y la integridad nacional de la República Argentina, bastaría aplicarle al pie de la letra la Constitución de Estados Unidos, convirtiendo en Estados a las que son y fueron provincias de un solo Estado". Y en respuesta a Sarmiento: "para falsear y 
que sus ideas federales tenían otra orientación; que la m i x t u r a y la inspiración en otras experiencias constitucionales eran suficientes para negar su interés por el ejemplo norteamericano. Sin embargo, los aspectos considerados en este trabajo revelan lo contrario. Por una parte, sus referencias a la experiencia constitucional de California, que demostraban que el federalismo era funcional en contextos sociales y políticos similares a los de Argentina. Y por otra la m i x t u ra, que resultó ser lo mismo que lo establecido por la Carta Fundamental de 1787 y El Federalista: es decir, dos esferas de poder, que se equilibran mutuamente, que son autónomas y se cooperan entre sí, y que son fortalecidas con un gobierno central que concentra potestades que están sobre las provincias. Años después, en 1869, escribía contrariando toda tentativa monarquista: "Todas esas ideas de construcciones monarquistas hubiesen estado en su lugar en 1864, cuando se trató de la monarquización de México, y probablemente pertenecen a este tiempo. Pero el establecimiento de la integridad de los Estados Unidos dejó todas esas especulaciones en la nada y repuso para siempre la solución republicana del problema de gobierno en la América de origen español ${ }^{103}$.

\section{BIBLIOGRAFÍA}

Adelman, Jeremy, Between Order and Liberty: Juan Bautista Alberdi and the Intellectual Origins of Argentine Constitutionalism, en Latin American Research Review, 42/2 (Texas, 2007), pp. 86-110.

Alberdi, Juan Bautista, Escritos Póstumos (Buenos Aires, 1901), III, XIII, XV.

-Estudios sobre la Constitución Argentina de 1853: Examen de la Constitución Provincial de Buenos Aires sancionada en 1854 (Buenos Aires, 1929).

-Obras Completas (Buenos Aires, 1960), III.

-Organización política y económica de la Confederación Argentina (Buenos Aires, 1856). - Bases y puntos de partida para la Organización Política Argentina (Buenos Aires, 2005). Alberini, Coriolano, La metafisica de Alberdi (La Plata, 1966).

BAQUÉ, Santiago, Influencia de Alberdi en la organización del Estado argentino (Buenos Aires, 1915).

Barros, Carolina, Alberdi, periodista en Chile (Buenos Aires, 1997).

Bosch, Beatriz, La Confederación Argentina 1854-1868 (Buenos Aires, 1998).

BOTANA, Natalio, El orden conservador, la política argentina entre 1880 y 1916 (Buenos Aires, 1977).

- Alberdi, Sarmiento y Mitre: tres proyectos de futuro para la era constitucional (Buenos Aires, 2004).

CANAL FeijOO, Bernardo Alberdi. La proyección sistemática del espiritu de mayo (Buenos Aires, 1961).

Carcano, Ramón J., Urquiza y Alberdi. Intimidades de una politica (Buenos Aires, 1938)

Dana, Salvador, La Constitución de 1853 y sus autores e inspiradores (Santa Fe, 1943).

bastardear la Constitución Nacional [...] no hay sino que comentarla con los comentarios de la Constitución de los Estados Unidos".

103 Alberdi, J. B., El Imperio del Brasil ante la democracia en América, cit. por CANAL Feijóo, B., Constitución y revolución (Buenos Aires), p. 548. 
DAVIS, Harold Eugene, Juan Bautista Alberdi, Americanist, en Journal of Inter-American Studies, 4/1 (Miami, 1962), pp. 53-65.

Di Meglio, Gabriel, La Mazorca y el orden rosista, en Prohistoria, 12 (Rosario, 2009), pp. 69-90.

Díaz Arana, Juan José, Influencia de Alberdi en la Constitución Nacional: juicio ante una controversia (Bueno Aires, 1947).

FaYT, Carlos, Fuentes de la Constitución Argentina (Buenos Aires, 1943).

Ferreyra, Raúl G., Orígenes. Sobre las Bases de Juan Bautista Alberdi y la Constitución Federal en el tiempo, en Academia. Revista sobre enseñanza del Derecho, 19 (Buenos Aires, 2012), pp. 143-228.

Galleti, Alfredo, Historia Constitucional Argentina (La Plata, 1974).

García, Manuel et al., Las fuentes de la Constitución Nacional. Los principios fundamentales del derecho público argentino (Buenos Aires, 2006).

García Mérou, M. Juan Bautista Alberdi (Ensayo crítico) (Buenos Aires, 1890)

Gargarella, Roberto, La sala de máquinas de la Constitución. Dos siglos de Constitucionalismo en América Latina (1810-2010) (Buenos Aires, 2014).

González Calderón, Juan A., Introducción al derecho público provincial (Buenos Aires, 1913).

-Doctrina constitucional: temas trascendentales de derecho político. Derecho público provincial y municipal. Cuestiones de derecho y jurisprudencia constitucional (Buenos Aires, 1928).

Halperin, Tulio, Prólogo, en Proyecto y Constitución de una Nación (Argentina 18461880) (Caracas, 1980).

Herrero, Alejandro, Juan Bautista Alberdi y su reflexión sobre América durante el régimen de Juan Manuel Rosas: (1835-1852), en Revista de Hispanismo Filosófico, 10 (Madrid, 2005), pp. 47-58.

LeVaGgi, Abelardo, Manual de historia del derecho argentino: parte general (Buenos Aires, 1998).

Levene, Ricardo, Historia de la Nación Argentina. Desde los orígenes hasta la organización definitiva de 1862 (Buenos Aires, 1946)

LinAREs, Segundo, Derecho Constitucional e instituciones politicas (Buenos Aires, 1981).

Lizondo Borda, Manuel, Juan Bautista Alberdi: su vida y su obra (Tucumán, 1960).

Lorenzo, Celso, Manual de Historia Constitucional Argentina (Rosario, 1997), II.

Lugones, Leopoldo, Historia de Sarmiento (Buenos Aires, 1945).

MasnatTA, Héctor et al., Constitución nacional: análisis de su reformar (Buenos Aires, 1993).

MAYER, Jorge, Alberdi y su tiempo, (Buenos Aires, 1973).

Oliver, Juan Pablo, El verdadero Alberdi: génesis del liberalismo económico (Buenos Aires, 1977).

Palcos, Alberto, Sarmiento (Buenos Aires, 1962).

Pérez Guilhou, Dardo, El pensamiento conservador de Alberdi y la Constitución de 1853 (Mendoza, 2003).

Polotto, María Rosario, La argentinidad de la constitución. Nuevos enfoques para el estudio de nuestra carta magna a principios del siglo XX (1901-1930), en Revista de Historia del Derecho, 37 (Buenos Aires, 2009), pp. 1-11.

SAMPAY, Arturo Enrique, La filosofía del iluminismo y la Constitución argentina de 1853 (Buenos Aires, 1944).

Sarmiento, Domingo Faustino, Argirópolis (Buenos Aires, 1913). 
Seco Villalba, José, Fuentes de la Constitución Argentina (Buenos Aires, 1943).

SEgOVIA, Eduardo, La historiografía argentina del romanticismo (Madrid, 1980).

SuÁreZ, Luis, Historia general de España y América (Madrid, 1989), XV.

SuberCaSEAuX, Bernardo, Juan Bautista Alberdi: modernidad y modernizaciones en el siglo XIX, en Estudios Avanzados, 25 (Santiago, 2016), pp. 1-19.

Wood, Gordon, The idea of America. Reflections on the Birth of the United States (Nueva York, 2011).

Zambonini, Alberto, El mensaje de Alberdi, gobernar es poblar (Buenos Aires, 1950).

Zimmermann, Eduardo, Judicial Institutions in Nineteenth-century Latin America (Londres, 1999).

Zuccherino, Ricardo, Juan Bautista Alberdi, ideólogo del siglo XXI (Buenos Aires, 1987). 